Atmos. Chem. Phys., 17, 6813-6823, 2017

https://doi.org/10.5194/acp-17-6813-2017

(c) Author(s) 2017. This work is distributed under

the Creative Commons Attribution 3.0 License.

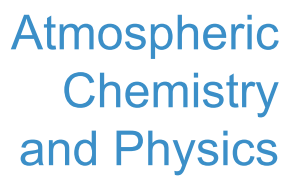

(c) (P)

\title{
Response of trace gases to the disrupted 2015-2016 quasi-biennial oscillation
}

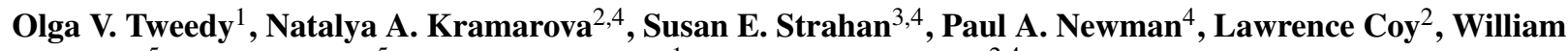 \\ J. Randel ${ }^{5}$, Mijeong Park ${ }^{5}$, Darryn W. Waugh ${ }^{1}$, and Stacey M. Frith ${ }^{2,4}$ \\ ${ }^{1}$ Department of Earth and Planetary Sciences, Johns Hopkins University, Baltimore, MD, USA \\ ${ }^{2}$ Science Systems and Applications Inc., Lanham, MD, USA \\ ${ }^{3}$ Universities Space Research Association, Columbia, MD, USA \\ ${ }^{4}$ NASA, GSFC, Greenbelt, MD, USA \\ ${ }^{5}$ National Center for Atmospheric Research, Boulder, CO, USA \\ Correspondence to: Olga V. Tweedy (otweedy1@jhu.edu)
}

Received: 28 January 2017 - Discussion started: 10 February 2017

Revised: 3 May 2017 - Accepted: 4 May 2017 - Published: 12 June 2017

\begin{abstract}
The quasi-biennial oscillation (QBO) is a quasiperiodic alternation between easterly and westerly zonal winds in the tropical stratosphere, propagating downward from the middle stratosphere to the tropopause with a period that varies from 24 to 32 months ( $\sim 28$ months on average). The QBO wind oscillations affect the distribution of chemical constituents, such as ozone $\left(\mathrm{O}_{3}\right)$, water vapor $\left(\mathrm{H}_{2} \mathrm{O}\right)$, nitrous oxide $\left(\mathrm{N}_{2} \mathrm{O}\right)$, and hydrochloric acid $(\mathrm{HCl})$, through the QBO-induced meridional circulation. In the 2015-2016 winter, radiosonde observations revealed an anomaly in the downward propagation of the westerly phase, which was disrupted by the upward displacement of the westerly phase from $\sim 30 \mathrm{hPa}$ up to $15 \mathrm{hPa}$ and the sudden appearance of easterlies at $40 \mathrm{hPa}$. Such a disruption is unprecedented in the observational record from 1953 to the present. In this study we show the response of trace gases to this QBO disruption using $\mathrm{O}_{3}, \mathrm{HCl}, \mathrm{H}_{2} \mathrm{O}$, and temperature from the Aura Microwave Limb Sounder (MLS) and total ozone measurements from the Solar Backscatter Ultraviolet (SBUV) Merged Ozone Data Set (MOD). Results reveal the development of positive anomalies in stratospheric equatorial $\mathrm{O}_{3}$ and $\mathrm{HCl}$ over $\sim 50-30 \mathrm{hPa}$ in May-September of 2016 and a substantial decrease in $\mathrm{O}_{3}$ in the subtropics of both hemispheres. The SBUV observations show near-record low levels of column ozone in the subtropics in 2016, resulting in an increase in the surface UV index during northern summer. Furthermore, cold temperature anomalies near the tropical
\end{abstract}

tropopause result in a global decrease in stratospheric water vapor.

\section{Introduction}

The quasi-biennial oscillation (QBO) is a quasiperiodic alternation between easterly and westerly zonal winds in the tropical stratosphere that is driven by a broad spectrum of vertically propagating Kelvin and mixed Rossby gravity waves along with smaller-scale gravity waves (Lindzen and Holton, 1968; Holton and Lindzen, 1972; Dunkerton, 1997). The alternating wind regimes (i.e., the easterly and westerly phases) propagate downward from the middle stratosphere to the tropopause with a period that varies from 24 to 32 months ( $\sim 28$ months on average).

There is also a QBO in ozone $\left(\mathrm{O}_{3}\right)$, which was first observed by Funk and Garnham (1962) in Australian midlatitude total-column $\mathrm{O}_{3}$ observations. Ramanathan (1963) showed the connection between the QBO in total $\mathrm{O}_{3}$ and the QBO in equatorial zonal winds using a series of ground stations spanning both hemispheres but most importantly noted the "out-of-phase" relationship between ozone in midlatitudes and the equator. Angell and Korshover (1964) found a QBO signal in Shanghai $\left(31.2^{\circ} \mathrm{N}\right)$ total $\mathrm{O}_{3}$ observations in the 1932-1942 period. Zawodny and McCormick (1991) used satellite $\mathrm{O}_{3}$ profile observations to show the ozone QBO vertical structure from 20 to $50 \mathrm{~km}$ and $50^{\circ} \mathrm{S}$ to $50^{\circ} \mathrm{N}$. Ran- 
del and $\mathrm{Wu}$ (1996) used numerical techniques to filter the QBO ozone structure showing the equatorial and midlatitude out-of-phase relationship and revealing the seasonal synchronization between the equatorial QBO and the largeamplitude winter-to-spring extratropical $\mathrm{O}_{3}$ anomalies that appear in both winter hemispheres.

Because most $\mathrm{O}_{3}$ is found in the lower stratosphere where its lifetime is more than 1 year, the tropical $\mathrm{O}_{3}$ distribution is strongly controlled by the tropical lower-stratosphere transport (Ling and London, 1986). Gray and Pyle (1989) used a two-dimensional (latitude vs. altitude) model to simulate the relationship between winds, temperatures, and the $\mathrm{O}_{3}$ distributions. Those modeled relationships were confirmed by the observations of Zawodny and McCormick (1991). The Gray and Pyle (1989) simulation revealed that the wave-induced QBO drove a secondary meridional circulation which modulated the $\mathrm{O}_{3}$ distribution. Assimilated meteorological data and modern transport models confirm these early results, and satellite instruments such as the Microwave Limb Sounder (MLS) have shown additional QBO impacts on water $\left(\mathrm{H}_{2} \mathrm{O}\right)$, hydrochloric acid $(\mathrm{HCl})$, nitrous oxide $\left(\mathrm{N}_{2} \mathrm{O}\right)$, and carbon monoxide (CO) (Schoeberl et al., 2008).

The QBO meridional circulation develops between the tropics and subtropics (from the equator to $\sim 30^{\circ} \mathrm{N}$ and $30^{\circ} \mathrm{S}$ ) to maintain the thermal wind balance between the descending QBO wind shear and its temperature anomaly. At the equator, westerly shear (westerlies aloft and easterlies below) is in balance with a downward-propagating, adiabatically warmed perturbation, while easterly shear (easterlies aloft and westerlies below) produces an upward, adiabatically cooled perturbation. The enhanced upwelling during easterly shear and reduced upwelling during westerly shear in the tropics are mass balanced by the changes in the subtropical descent. The circulation is "completed" by the equatorial divergence/convergence of air at the levels of maximum easterly/westerly winds (Choi et al., 2002). The QBO-induced meridional circulation acts on local trace gas gradients to modify their distributions (Gray and Chipperfield, 1990). $\mathrm{O}_{3}$ responds with increased/decreased values in the tropics and decreased/increased values in the extratropics during descending westerly/easterly shear.

QBO effects on composition are found throughout the extratropics. QBO-driven column $\mathrm{O}_{3}$ anomalies originating in the southern subtropics in early winter reach $60^{\circ} \mathrm{S}$ by the early spring (Gray and Ruth, 1993; Randel and Wu, 1996; Kinnersley and Tung, 1998). Strahan et al. (2015) also showed a transport pathway by which the midlatitude middle-stratosphere QBO signal affects polar $\mathrm{O}_{3}$ depletion by modulating Antarctic inorganic chlorine.

The QBO has been widely analyzed because it is a major source of stratospheric $\mathrm{O}_{3}$ interannual variability (Baldwin et al., 2001), and the QBO in total-column $\mathrm{O}_{3}$ is a dominant factor controlling interannual variations in surface ultraviolet levels (Udelhofen et al., 1999). Further, the detection and attribution of long-term $\mathrm{O}_{3}$ changes caused by ozone-depleting substances (ODSs) requires accurate statistical models that include QBO regression terms in order to remove the QBOdriven natural $\mathrm{O}_{3}$ variability and thereby reveal the residual ODS-forced ozone depletion (e.g., Stolarski et al., 1991). Hence, investigating the QBO-driven variability is fundamental to understanding $\mathrm{O}_{3}$ levels and trends and the resulting changes to surface ultraviolet (UV) radiation.

During the Northern Hemisphere (NH) winter of 20152016, radiosonde observations revealed that the normal downward propagation of the QBO westerly phase was disrupted by the upward propagation of westerlies from $\sim 30 \mathrm{hPa}$ up to $15 \mathrm{hPa}$ and the sudden appearance of easterlies at $40 \mathrm{hPa}$ (Newman et al., 2016; Osprey et al., 2016). This disruption began in November 2015, and the easterlies were fully developed by March 2016. Such a disruption is unprecedented in the equatorial wind observational record from 1953-present. Osprey et al. (2016) showed that this anomalous event was linked to the transport of easterly momentum from the northern extratropics into the equatorial region, and Coy et al. (2017), using meteorological analysis fields beginning in 1980, showed that the 2015-2016 tropical easterly momentum flux had the largest values in DecemberFebruary. None of these studies examined the changes in $\mathrm{O}_{3}$ or other trace gases during 2015-2016.

In this study we investigate the response of stratospheric trace gases to the 2015-2016 event. We quantify the impact of the disruption on $\mathrm{O}_{3}$ and other trace gases and further compare their observed changes to the expected behavior due to the QBO in the absence of the disruption. Furthermore, we examine the interannual variations in total ozone and water vapor.

\section{Methods and data}

We use Aura MLS version 4.2 level 2 measurements of temperature $(T), \mathrm{O}_{3}$, and $\mathrm{HCl}$ from January 2005 to February 2017 between 10 and $100 \mathrm{hPa} . \mathrm{O}_{3}$ and $T$ are reported on a fixed vertical grid with 12 surfaces per decade change in pressure between 1000 and $1 \mathrm{hPa} ; \mathrm{HCl}$ is reported on 6 pressures per decade. $\mathrm{O}_{3}$ and $\mathrm{HCl}$ have a vertical resolution of $\sim 3 \mathrm{~km}$ in the pressure range used in this analysis, while the vertical resolution of $T$ is $\sim 4 \mathrm{~km}$. Although $\mathrm{O}_{3}$ and $T$ are reported on the same pressure grids, their vertical resolution is not the same because the number of independent measurements that the instrument makes varies between MLS $T$ and $\mathrm{O}_{3}$ (Livesey et al., 2015). $\mathrm{O}_{3}$ accuracy varies from 50 to $300 \mathrm{ppb}$ between 100 and $10 \mathrm{hPa}$, while $\mathrm{HCl}$ accuracy is estimated at $\sim 10 \%$. MLS temperatures have a $-1 \mathrm{~K}$ bias in the stratosphere with respect to correlative measurements. Details on MLS measurements, data quality, and improvements on previous versions can be found in the MLS v4.2 data quality document (Livesey et al., 2015).

We examine total-column $\mathrm{O}_{3}$ during the anomalous QBO event using total $\mathrm{O}_{3}$ observations from the Solar Backscat- 
ter Ultraviolet (SBUV) Merged Ozone Data Set (MOD). The MOD is constructed from monthly zonal mean ozone profiles by individual SBUV instruments, providing the longest available satellite-based time series of profile and total $\mathrm{O}_{3}$ from a single instrument type (Frith et al., 2014). The MOD used here includes observations from January 1980 to the present to evaluate the temporal and spatial distribution of total $\mathrm{O}_{3}$.

We use monthly averaged analyses of meteorological data on constant pressure levels from the Modern-Era Retrospective analysis for Research and Applications-Version 2, (MERRA-2) (Bosilovich et al., 2015) to determine the vertical wind shear and QBO phase. The MERRA-2 analysis begins in January 1980. Coy et al. (2016) showed that MERRA2 produces a realistic QBO from 1980 to 2016, a period encompassing $15 \mathrm{QBO}$ cycles. We show changes in the meridional circulation due to the disrupted QBO using the vertical component of the MERRA-2 residual mean meridional circulation, $\bar{w}^{*}$ (Andrews et al., 1987), which is calculated using 3-hourly output.

To determine the impact of the 2015-2016 disruption on the distribution of trace gases, we create a QBO composite ("QBO climatology") for each analyzed dynamical variable ( $T$, zonal winds $(\bar{u})$, and upwelling by the residual circulation $\left.\left(\bar{w}^{*}\right)\right)$ and trace species $\left(\mathrm{O}_{3}, \mathrm{HCl}\right.$, and total $\left.\mathrm{O}_{3}\right)$. These QBO composites include all available data except for 2015-2016. The composite is based on the month of change from zonal mean easterly (negative) to westerly (positive) vertical wind shear at $40 \mathrm{hPa}$. This is identified by month " 0 " in the figures. Compositing based on this criterion emphasizes that chemical trace gases are most closely related to the changes in the wind shear $\left(\frac{\partial \bar{u}}{\partial z}\right.$ or $\bar{u}_{z}$ ), not the zonal wind $(\bar{u})$ (Baldwin et al., 2001). Compositing dates (month 0 ) for each QBO cycle are listed in Table 1. Prior to compositing, we use monthly $\bar{u}$ data to compute $\bar{u}_{z}$ as a first vertical derivative of an unevenly spaced array of $\bar{u}$ using three-point (quadratic) Lagrangian interpolation. The annual cycle was removed from $T, \bar{w}^{*}$, and trace gases to better isolate $\mathrm{QBO}$ variations, and values are shown in percent difference relative to the monthly climatology, except for the total-column $\mathrm{O}_{3}$, which is shown as an absolute difference in Dobson units (DU). Anomalies due to the 2015-2016 event are calculated as the difference between "2015-2016" and the composite, with values larger than 2 standard deviations considered "significant".

Empirical orthogonal function (EOF) analysis has been applied to specify the instantaneous state of the QBO (Wallace et al., 1993). The two leading EOFs (EOF1 and EOF2) were derived from the deseasonalized monthly mean zonal wind data from Singapore radiosondes.

Interannual changes in global stratospheric water vapor and cold-point tropical tropopause temperatures were analyzed by forming time series from multiple observational data sets. Data were deseasonalized to isolate anomalies due to the QBO. Time series of stratospheric water vapor anomalies were derived from combined HALOE (Halogen Occultation Experiment; 1991-2005) and Aura MLS (2004-
2016) satellite measurements. These data represent nearglobal $\left(\sim 60^{\circ} \mathrm{N}-60^{\circ} \mathrm{S}\right)$ averages in the lower stratosphere $(83 \mathrm{hPa})$. HALOE and MLS data were combined using the overlap period during 2004-2005. Cold-point temperatures are derived from radiosonde data (1991-2016) and GPS radio occultation data (2001-2016). More details of the data and analysis are provided by Randel and Jensen (2013).

\section{Results}

\subsection{The response of the equatorial stratosphere to the anomalous QBO event}

Prior to 2015, wind observations show the robust features of the QBO's zonal wind pattern of descent in the middle and lower equatorial stratosphere (Newman et al., 2016; Coy et al., 2017). The $\bar{u}$ composite in Fig. 1 (top, column a) shows typical descending easterlies (blue) and westerlies (red) with zero wind shear (thick, solid black contours). The alternating regime of downward-propagating wind shear leads to a modification of lower-stratospheric tracers. Composites of tropical $\mathrm{O}_{3}$ and $\mathrm{HCl}$ (Fig. 1a) show decreases/increases in mixing ratios, relative to the climatological seasonal values, during negative (easterly)/positive (westerly) wind shear. This $\mathrm{O}_{3}$ and $\mathrm{HCl}$ behavior results from the QBO-induced ("secondary") meridional circulation, acting on local gradients of these chemical tracers (Gray and Chipperfield, 1990). A downward (adiabatically warmed) perturbation (decreased $\bar{w}^{*}$ and increased $T$ ) is associated with descending westerly wind shear (positive $\bar{u}_{z}$ ), while an upward (adiabatically cooled) perturbation is associated with easterly shear (negative $\left.\bar{u}_{z}\right)$. Since the tracer's tendency $\left(\bar{\chi}_{t}\right)$ is proportional to $-\bar{w}^{*} \bar{\chi}_{z}$ and mixing ratios of both chemical species increase with height in the lower stratosphere (positive vertical gradient, $\left.\bar{\chi}_{z}\right), \mathrm{O}_{3}$ and $\mathrm{HCl}$ decrease with time when $\bar{w}^{*}$ increases. The opposite is true for a downward perturbation (decreased $\bar{w}^{*}$ ). This is supported by the good agreement between the analyzed $\bar{w}^{*}$ and observed $T, \mathrm{O}_{3}$, and $\mathrm{HCl}$ composites with vertical wind shear. As discussed in the introduction, horizontal transport completes the circulation and also contributes to some changes in tropical stratospheric composition (not shown).

In late 2015 westerlies were displaced upward between 30 and $15 \mathrm{hPa}$, and anomalous easterlies developed at $\sim 40 \mathrm{hPa}$ in early 2016 (Newman et al., 2016; Coy et al., 2017); see Fig. 1b (top). During the northern spring the anomalously ascending westerlies reverted back to a more typical descent, reaching $50 \mathrm{hPa}$ in September 2016 and $70 \mathrm{hPa}$ in February 2017. The vertical residual velocity, $\bar{w}^{*}$ (Fig. $1 \mathrm{~b}$ bottom), responded to the changes in equatorial zonal winds during 2015-2016 with decreased upwelling in association with the westerly shear and increased upwelling below the easterly maximum. A strong positive temperature perturbation developed in the 50-30 hPa layer (westerly shear zone) due to this 
Table 1. The QBO composite dates (month 0).

\begin{tabular}{|c|c|c|c|c|c|c|c|c|}
\hline QBO cycle & 1 & 2 & 3 & 4 & 5 & 6 & 7 & 8 \\
\hline Month 0 & 1982-06 & 1984-10 & 1987-06 & 1989-12 & 1992-06 & 1994-09 & 1996-11 & 1998-09 \\
\hline QBO cycle & 9 & 10 & 11 & 12 & 13 & 14 & 15 & \\
\hline Month 0 & $2001-10$ & 2003-12 & 2006-02 & 2008-01 & $2010-06$ & $2012-12$ & 2015-05 & \\
\hline
\end{tabular}
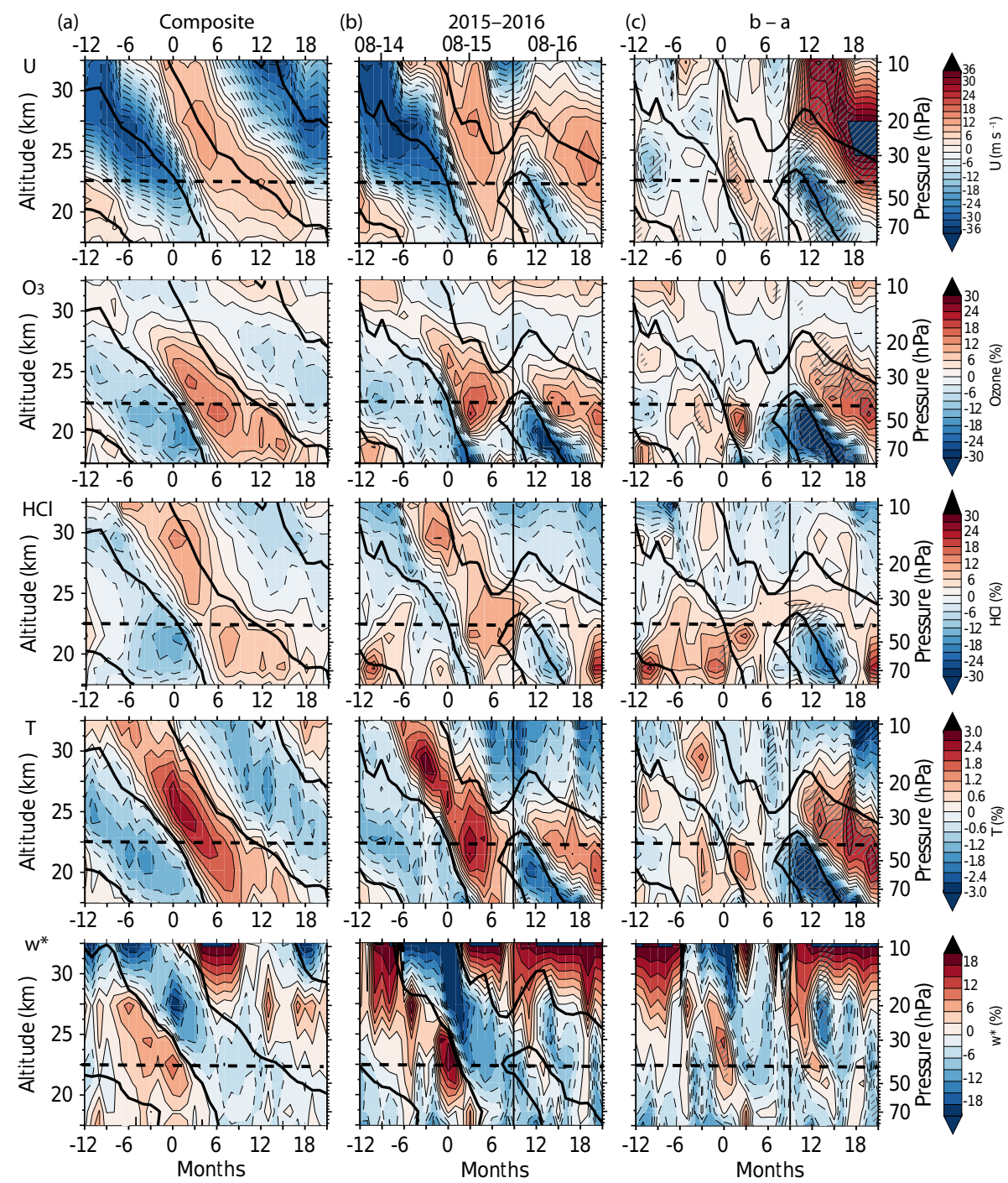

Figure 1. The rows show the MERRA-2 zonal mean zonal wind component, $\bar{u}\left(\mathrm{~m} \mathrm{~s}^{-1}\right)$, deseasonalized $\mathrm{MLS} \mathrm{O}_{3}, \mathrm{HCl}$, temperature $(T)$, and vertical component of the MERRA-2 residual circulation $\left(\bar{w}^{*}\right)$, as a function of time and pressure (in percent change from long-term monthly averages), averaged over $5^{\circ} \mathrm{S}-5^{\circ} \mathrm{N}$. Column (a) shows the composite of the easterly-to-westerly shear transitions based on four shear transitions at $40 \mathrm{hPa}$. Column (b) shows the 2015-2016 QBO cycle, which includes the data from May 2014 to February 2017, with month 0 in May 2015. Column (c) shows the difference between the 2015-2016 event and the climatology (b-a) with hatching indicating regions with absolute difference (b-a) larger than 2 standard deviations The thick black contours denote zero wind shear. The horizontal dashed line indicates the $40 \mathrm{hPa}$ level, while the vertical line indicates February 2016.

reduced upwelling, while a strong negative perturbation developed in the easterly shear zone - due to the enhanced upward motion. Although analyzed $\bar{w}^{*}$ is noisy and involves greater uncertainty because of its highly derived nature, the excellent agreement between the wind shear and temperature changes (Fig. 1b bottom panels) provides evidence of secondary circulation changes resulting from the anomaly. 
The circulation anomalies created by the 2015-2016 event altered stratospheric composition patterns (Fig. $1 \mathrm{~b} ; \mathrm{O}_{3}$ and $\mathrm{HCl})$ relative to the composites seen in the left column. Changes in $\mathrm{O}_{3}$ and $\mathrm{HCl}$ are in good agreement with changes in the wind shear and temperature (and thus $\bar{w}^{*}$ ). Prior to November 2015, both trace gases followed similar tendencies to their composites. Beginning in February 2016 (black vertical line in Fig. 1b), $\mathrm{O}_{3}$ and $\mathrm{HCl}$ increased between 50 and $30 \mathrm{hPa}$ (due to the reduced upward motion) and decreased below $50 \mathrm{hPa}$ (due to the enhanced upward motion). When the composites are subtracted from the last QBO cycle (Fig. 1c), QBO-induced anomalies in $T, \mathrm{O}_{3}$, and $\mathrm{HCl}$ are seen to be colocated with the changes in wind shear during the last $\mathrm{QBO}$ cycle and anomalies in $u, T$, and $\mathrm{O}_{3}$ are larger than 2 standard deviations (hatched gray lines), indicating that their changes were driven by the 2015-2016 QBO disruption.

The unprecedented nature of the 2015-2016 event is demonstrated in Fig. 2 showing "the orbits of the QBO" in two-dimensional phase space, based on the projections of two leading empirical orthogonal functions (EOF1 and EOF2), following Wallace et al. (1993). QBO orbits are used to quantify the amplitude and phase propagation among the QBO cycles. Each point in this figure describes the instantaneous state of the QBO, described by the amplitude and phase angle of the vector in polar coordinates and specified in terms of variables (EOF1 and EOF2) that define the vertical structure of the zonal wind. EOF1 reflects the negative correlation between zonal wind fluctuations at 10 and $70 \mathrm{hPa}$, while EOF2 indicates the variability at intermediate levels. Time progression corresponds to counterclockwise transits and each orbit corresponds to an individual QBO cycle.

Prior to 2016, the QBO orbits (blue dots in Fig. 2) are roughly circular and data points are distributed uniformly along the orbits, indicating the remarkably uniform structure and nearly constant amplitude of the QBO in this record (1987-2015). During this time, EOF1 and EOF2 combined explain $\sim 95.5 \%$ of the variance of the deseasonalized smoothed time series of zonal winds between 70 and $10 \mathrm{hPa}$. Based on this stability, EOF1 and EOF2 are commonly used to isolate the variability related to the QBO when deriving ODS-induced changes in long-term ozone records.

The repetitive QBO pattern was disrupted in 2016, as shown by the red points that deviate from the regular circular pattern. The smaller amplitude (closer to the center) of EOF1 and EOF2 in Fig. 2 during the disruption means the zonal winds either are weaker than the typical QBO or do not fit the EOFs well. Analysis of the variance explained by two leading EOFs shows that the first two EOF patterns do not match the disruption very well, with the lowest percent variance $(\sim 71 \%)$ explained by the two EOFs in the entire data record occurring during the disruption (not shown). Such disruptions add unpredictable variability to the time series, reducing the accuracy of stratospheric ozone trends determined by multivariate regressions.

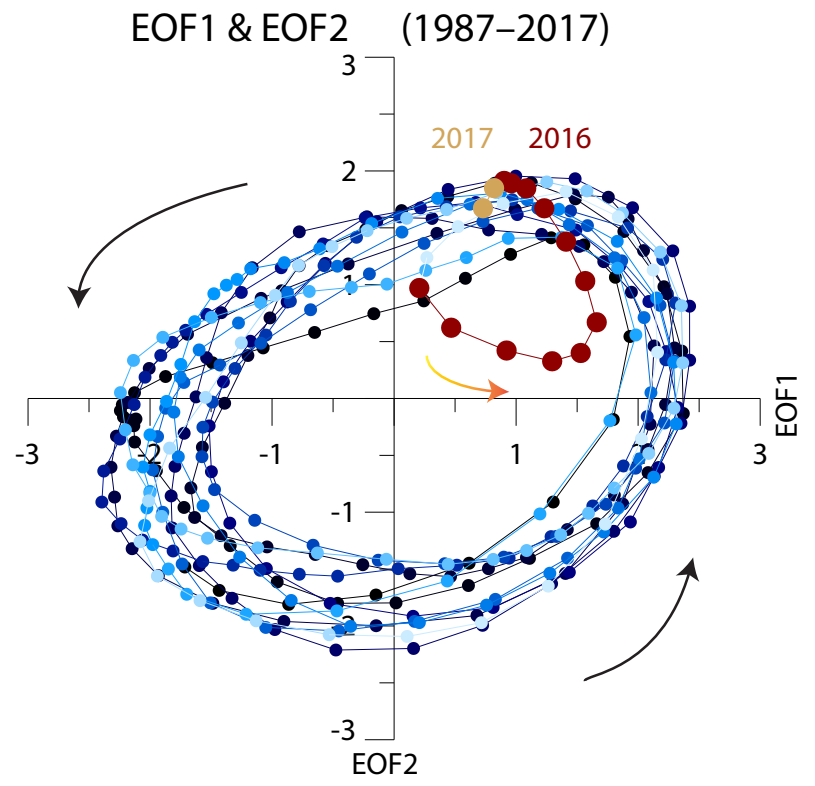

Figure 2. Phase space diagram of the projection of the monthly equatorial zonal wind anomalies onto spatial structures EOF1 and EOF2. Time progression coincides with counterclockwise orbit transits. Dots represent each month from January 1987 to February 2017. Different shades of blue indicate different years from 1987 to 2015 (from darker to lighter), while red and yellow dots correspond to 2016 and 2017 , respectively.

\subsection{Latitudinal changes in ozone}

The stratospheric impact of the 2015-2016 event extends into the extratropics. Figure 3 shows the evolution of $\mathrm{O}_{3}$ for the composite (left), 2015-2016 (middle) and their difference (right). Fig. 3a, b, and c show $\mathrm{MLS}_{3}$ at $38 \mathrm{hPa}$, the pressure level of maximum $\mathrm{O}_{3}$ anomaly during the $\mathrm{NH}$ summer of 2016. As shown in the composite (Fig. 3a), the positive $\mathrm{O}_{3}$ perturbation during the westerly shear in the tropics and the negative perturbations in the extratropics are replaced by anomalies of opposite signs as the wind shear reverses to easterly 12-14 months later. However, in 2016 (Fig. 3b) the $40 \mathrm{hPa}$ westerly shear changes to a weak easterly shear for only a short time interval (January-April) before switching back to westerly shear (note that the wind shear at $30 \mathrm{hPa}$ remains westerly). $\mathrm{O}_{3}$ responds by decreasing/increasing in mixing ratios during the easterly/westerly shear changes. The $\mathrm{O}_{3}$ anomalies due to the 2015-2016 event are highlighted in Fig. 3c, which shows large differences after February 2016 (black line). A strong negative tropical $\mathrm{O}_{3}$ perturbation developed by early spring 2016, propagating to the extratropics in both hemispheres by the end of the NH summer. In the equatorial region, a positive perturbation replaced the negative $\mathrm{O}_{3}$ perturbation as the wind shear switched back to westerly. QBO-induced anomalies after February 2016 are larger than 2 standard deviations. 


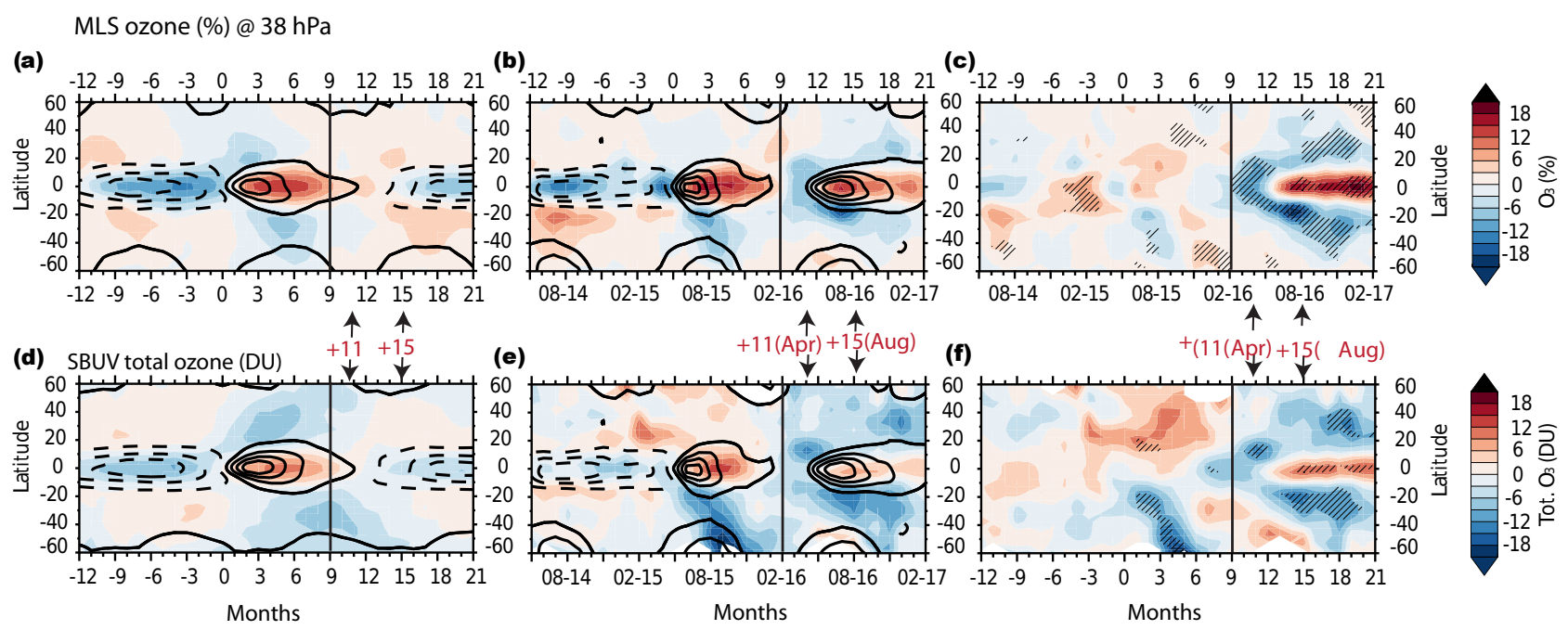

Figure 3. Latitude and time evolution of MLS ozone at $38 \mathrm{hPa}$ (top row) for (a) the composite, (b) 2015-2016, and (c) their difference (b-a), highlighting the anomalies due to the disruption. MLS ozone values are shown in percent change from long-term monthly averages with contour intervals every $3 \%$ (zero contour is omitted). The bottom row shows the deseasonalized SBUV total ozone (in Dobson units, contour intervals every 3 DU) for (d) the composite, (e) 2015-2016, and (f) their difference (e-d). Black thick solid and dashed contours show westerly and easterly vertical wind shear, respectively, for (a, d) the composites and (b, e) 2015-2016. MLS (SBUV) composites are based on 4(14) transitions from easterly to westerly vertical wind shear at $40 \mathrm{hPa}$. Vertical black line highlights +9 months after wind shear reversal from negative to positive (month 0 ), corresponding to February 2016 in (b) and (e), while arrows indicate ozone at +11 and +15 months after month 0, corresponding to April 2016 and August 2016 in (b) and (e). Gray hatching in (c) and (f) indicates regions with the absolute difference between 2015-2016 and the composites being larger than 2 standard deviations.

The $2016 \mathrm{NH}$ summer positive tropical $\mathrm{O}_{3}$ anomaly at $30-50 \mathrm{hPa}$ - the level of maximum $\mathrm{O}_{3}$ number density contributed to substantial changes in the total-column $\mathrm{O}_{3}$. As in the $38 \mathrm{hPa} \mathrm{O}_{3}$ from MLS (Fig. 3, top), the typical QBO behavior of SBUV total $\mathrm{O}_{3}$ (Fig. 3d) contrasts with the anomalous 2015-2016 behavior (Fig. 3e), with their difference (Fig. 3f) highlighting the 2016 anomalies. The SBUV total $\mathrm{O}_{3}$ QBO composite is based on 14 transitions of wind shear at $40 \mathrm{hPa}$ (excluding 2015-2016). Total $\mathrm{O}_{3}$ was deseasonalized and values are shown as absolute difference from the monthly climatology (in Dobson units). This SBUV composite captures the major features of the typical QBO and the $\mathrm{O}_{3}$ perturbations.

Prior to February 2016, Fig. 3f shows small total $\mathrm{O}_{3}$ differences except for the large midlatitude anomalies from 0 to +6 months in the southern (negative anomaly) and northern (positive anomaly) hemispheres. However, only the negative anomaly in the southern midlatitudes is larger than 2 standard deviations. The cause of these anomalies prior to the 2015-2016 disruption remains unclear and is the subject of ongoing investigation. After February 2016 (black line in Fig. 3e), there is a large decrease in total ozone in the extratropics and midlatitudes of both hemispheres and the total $\mathrm{O}_{3}$ differences between composite and last QBO cycle (Fig. 3f) are very similar to the differences in $38 \mathrm{hPa} \mathrm{O}_{3}$ from MLS (Fig. 3c). This strongly suggests that the 2015-2016 event had a significant impact on both tropical and extratropical total $\mathrm{O}_{3}$.

\subsection{Temporal and spatial morphology of ozone in April and August 2016}

Large negative $\mathrm{O}_{3}$ anomalies in the lower stratosphere start in April 2016 in the tropics and propagate to the extratropics by August 2016. Note that these two months occur at 11 and 15 months after month 0 on the "composited" time axes and are indicated by arrows in Fig. 3. Therefore, we compare the latitudinal and vertical extent of the QBO-induced anomalies in $T$ and $\mathrm{O}_{3}$ during these two months (Fig. $4 \mathrm{~b}$ and d) to the expected behavior based on the composite $11(+11)$ and 15 $(+15)$ months after the wind shear reversal (Fig. 4a and c). In agreement with Fig. 1b, in April 2016 the anomalous easterly shear below $40 \mathrm{hPa}$ (dashed horizontal line in Fig. 1b) leads to strong negative $T$ and $\mathrm{O}_{3}$ perturbations in the tropics, while the appearance of ascending westerly shear leads to weak tropical $T$ and $\mathrm{O}_{3}$ increases between 20 and $40 \mathrm{hPa}$. By August 2016, the westerly shear strengthens and descends to $30-50 \mathrm{hPa}$ resulting in strong positive $T$ and $\mathrm{O}_{3}$ perturbations in this layer, while the easterly shear below $50 \mathrm{hPa}$ leads to negative perturbations in the equatorial $\left(10^{\circ} \mathrm{N}-10^{\circ} \mathrm{S}\right)$ stratosphere. This is consistent with our understanding of trace gas response to changes in tropical upwelling. The consistency of $\mathrm{O}_{3}$ and $T$ anomalies during 2015-2016 is evidence of circulation changes. 

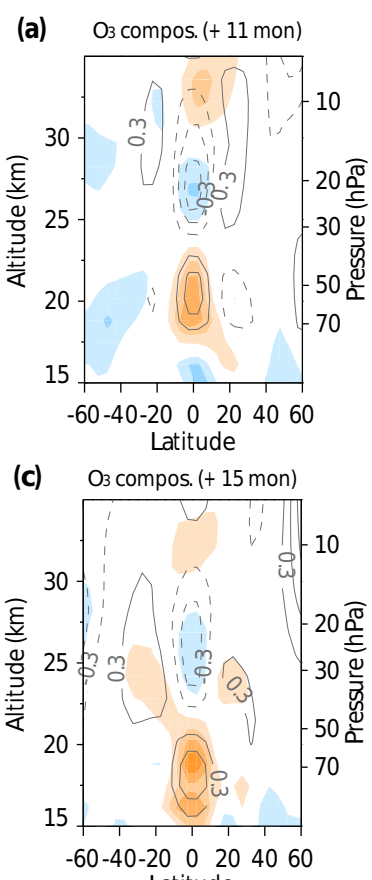

Latitude

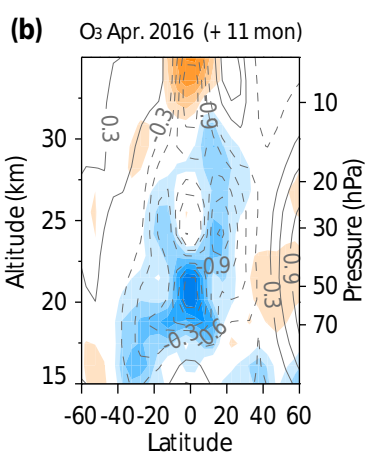

(d) $\mathrm{O}_{3}$ Aug. 2016 (+ 15 mon)

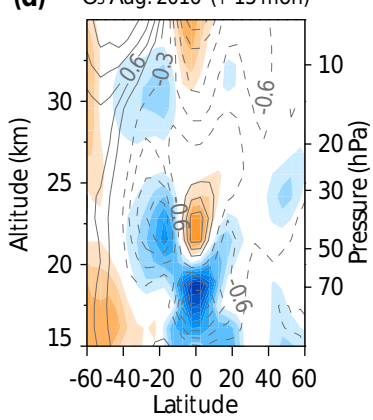

Latitude

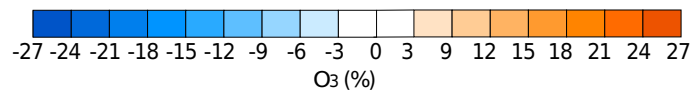

Figure 4. Latitude-height cross sections of deseasonalized MLS ozone (filled) and temperature (gray contours) in the composite (a) 11 and (c) 15 months after the wind shear reversal based on four QBO cycles and during (b) April (+11 months) and (d) August 2016 (+15 months). Ozone and temperature values are shown in percent change from long-term monthly averages with contour intervals every 3 and $0.3 \%$, respectively (zero contour is omitted).

In the subtropics, the deseasonalized $\mathrm{O}_{3} \mathrm{QBO}$ signature is out of phase with that at the equator, in agreement with Fig. 3b. In August 2016, strong negative $\mathrm{O}_{3}$ perturbations develop during the $\mathrm{NH}$ summer on both sides of the equator (although they are much stronger in the winter Southern Hemisphere) as a response to the QBO-induced meridional circulation. In the composites at +11 and +15 months (Fig. 4a and c) anomalies in MLS $\mathrm{O}_{3}$ and $T$ are opposite to those observed in April and August 2016 (Fig. 4b and d) due to the descending easterly shear. Thus, $\mathrm{O}_{3}$ is responding as expected to a QBO-induced meridional circulation, but this period is anomalous with respect to a normal QBO progression.

The observed 2015-2016 anomalies are unique in the total $\mathrm{O}_{3}$ record. Figure 5 compares the latitudinal distribution of deseasonalized total $\mathrm{O}_{3}$ from April and August 2016 (in red) to the total $\mathrm{O}_{3}$ composite (the average of the 14 composited QBO cycles) shown in Fig. 3d at +11 and +15 months, respectively (in black). Total $\mathrm{O}_{3}$ from each individual QBO cycle included in the composite is shown in blue, with light blue shading indicating the range of total $\mathrm{O}_{3}$ from all QBO cycles
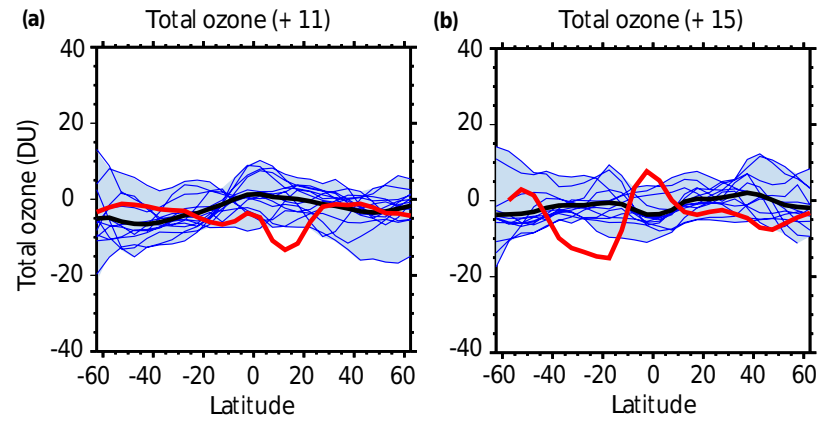

Figure 5. (a) Deseasonalized SBUV total ozone (in Dobson units) as a function of latitude 11 months after wind shear reversal from easterly to westerly from 14 QBO cycles prior to 2015-2016 (blue lines), the composite (black line) based on 14 QBO cycles, and 2015-2016 (April 2016; red line). (b) The same as (a) only for total ozone at +15 months, corresponding to August 2016. The blue shading shows the observed $\mathrm{O}_{3}$ range at +11 and +15 months, respectively, for all 14 QBO cycles (excluding the 2015-2016 event).

(excluding 2015-2016). In the absence of the disruption, we expect total $\mathrm{O}_{3}$ at +11 (Fig. 5a) and +15 (Fig. 5b) months to lie within the blue shaded range of past observations. Instead, in April 2016 total $\mathrm{O}_{3}$ is lower than during other QBO cycles in the $\mathrm{NH}$ tropics $\left(10-20^{\circ} \mathrm{N}\right)$. Furthermore, during August 2016 total ozone is higher at the equator and lower/near the edge in the extratropics between 10 and $40^{\circ} \mathrm{S} / 30$ and $50^{\circ} \mathrm{N}$ compared to other QBO cycles.

Calculations suggest that anomalously low total-column $\mathrm{O}_{3}$ at $22.5^{\circ} \mathrm{S}$ in August 2016 increased the monthly zonal mean surface clear-sky UV index by $\sim 8.5 \%$ compared to the 36-year mean (Newman and McKenzie, 2011). Increased surface UV radiation has a harmful effect on health by damaging cells, DNA, and increasing the risk of developing skin cancer. Increased exposure to UV in plants leads to enhanced plant fragility, growth limitation, and yield reduction affecting our ability to secure food production (Caldwell et al., 1995; Tevini, 1993).

\subsection{QBO-driven changes in total ozone and water vapor in the context of long-term time series}

Examination of the interannual variations in SBUV monthly and zonal mean total $\mathrm{O}_{3}$ shows very low total $\mathrm{O}_{3}$ values in the extratropics during spring and summer of $2016 \mathrm{com}$ pared to other years within this observational record. Figure 6 displays the time series for April (top panels) and August (bottom panels) total $\mathrm{O}_{3}$ values in the northern and southern extratropics. The regions shown are locations with large anomalies in Fig. 3f. The individual $1 \sigma$ error estimates are shown as the vertical gray bars in Fig. 6, while the horizontal line is the 2016 value. Each of these plots shows that the 2016 value was the record or near-record low in the more than 40 years of the SBUV data. 
(a) Apr $10-15^{\circ} \mathrm{S}(39 \%, 98 \%)$

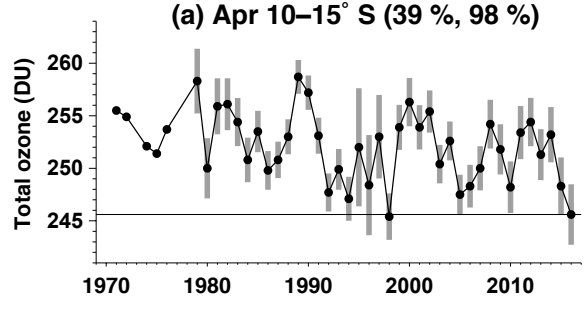

(c) Aug $15-20^{\circ} \mathrm{S}(65 \%, 100 \%)$

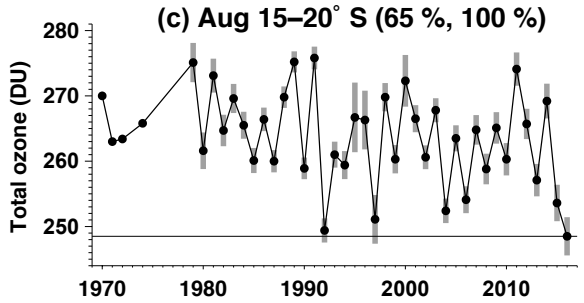

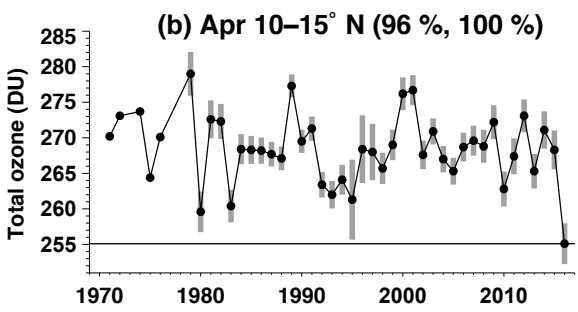

(d) Aug $45-50^{\circ} \mathrm{N}(55 \%, 100 \%)$

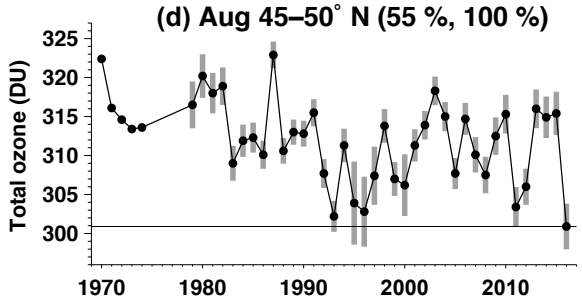

Figure 6. SBUV total ozone (in Dobson units) time series from 1970 to 2016 for April, averaged over (a) $10^{\circ} \mathrm{S}-15^{\circ} \mathrm{S}$ and (b) $10-15^{\circ} \mathrm{N}$, and for August, averaged over (c) $15-20^{\circ} \mathrm{S}$ and (d) $45-50^{\circ} \mathrm{N}$. Vertical bars show $1 \sigma$ uncertainties in the measurements. The horizontal line shows the total ozone value in April or August 2016 and the panel captions show the percentage estimates of the 2016 value that are the lowest and amongst the lowest $20 \%$ of all values. The probability that the 2016 values were record lows was estimated using 10000 Monte Carlo simulations of the monthly means in the time series (Frith et al., 2014).

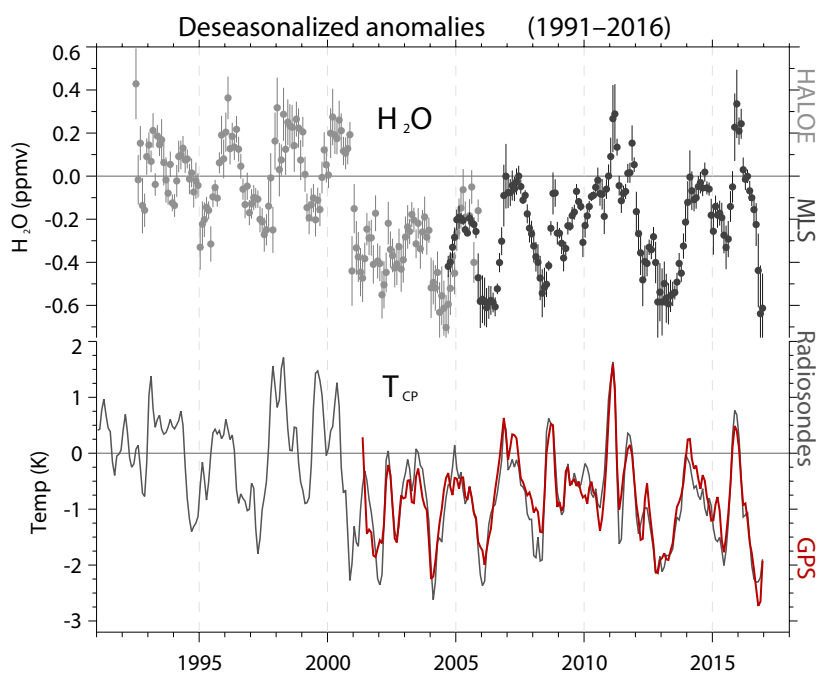

Figure 7. Observed variations in lower-stratospheric water vapor and tropical cold-point tropopause temperatures from satellite measurements over the period 1992-2016. Water vapor data are deseasonalized near-global averages at $83 \mathrm{hPa}$ from combined HALOE and MLS satellite measurements. Each dot represents a monthly average. Temperatures are deseasonalized anomalies derived from radiosonde data (black line) and GPS radio occultation data (red line, for 2001-2016). Vertical bars are $1 \sigma$ standard deviations of the monthly averages.

Near-record low total $\mathrm{O}_{3}$ in the extratropics during spring and summer 2016 is due to the 2015-2016 QBO disruption event. As shown in Fig. 3e, beginning about February 2016 the disruption in the descent of easterly zonal winds led to lower $\mathrm{O}_{3}$ values in both the northern and southern extratropics and persisted into the fall of 2016. The ozone anomalies, shown in Fig. 3e, are up to $-12 \mathrm{DU}$ at $12.5^{\circ} \mathrm{N}$ in April 2016 and $-15 \mathrm{DU}$ at $17.5^{\circ} \mathrm{S}$ in August 2016. This strongly contrasts with the expected behavior (Fig. 3d) that would have been either near zero or small positive anomalies.

The 2015-2016 QBO event also significantly impacted the global amount of stratospheric water vapor in $2016 . \mathrm{H}_{2} \mathrm{O}$ enters the stratosphere from the troposphere primarily in the tropics. The amount of $\mathrm{H}_{2} \mathrm{O}$ in the stratosphere is controlled by the tropical tropopause temperature ("cold-point tropopause temperatures", or $T_{\mathrm{cp}}$ ) with colder $T_{\mathrm{cp}}$ resulting in less $\mathrm{H}_{2} \mathrm{O}$ entering the tropical stratosphere from the troposphere. Figure 7 demonstrates a very strong correlation of stratospheric water vapor anomalies with $T_{\mathrm{cp}}$ (also see Randel and Jensen, 2013). In 2016, cold tropical tropopause temperatures (in balance with anomalous easterlies) led to a global decrease in the stratospheric $\mathrm{H}_{2} \mathrm{O}$ in OctoberDecember 2016. Global $\mathrm{H}_{2} \mathrm{O}$ in November is amongst the lowest in the record (1992-2016) due to very low $T_{\mathrm{cp}}$.

In addition to the QBO disruption, there was a strong El Niño in the 2015-2016 winter (Hu et al., 2016). While changes in the global water content and stratospheric ozone from late spring to the end of fall 2016 are attributed mostly to the unprecedented QBO event, El Niño could strongly influence the lower stratosphere during the winter of 2016. Previous studies showed a cooling of the tropical lower stratosphere and strengthening of the Brewer-Dobson circulation during El Niño (Randel et al., 2009; Calvo et al., 2010) followed by an associated decrease in ozone and increase in $\mathrm{H}_{2} \mathrm{O}$ in this region. The impact of the El Niño-Southern Os- 
cillation (ENSO) on stratospheric water vapor, however, is nonlinear and often depends on the phase of the QBO (Liess and Geller, 2012), time of the year (early or late in the winter), and location (central or eastern Pacific) where the ENSO maximum occurs (Garfinkel et al., 2013). The interplay between El Niño and the QBO disruption during the 2015-2016 boreal winter is not well understood and their relative importance on trace gas distribution requires a detailed investigation.

\section{Concluding remarks}

This study demonstrates that the 2015-2016 QBO disruption had a substantial impact on the composition of the stratosphere. It led to a modified circulation that reduced the equatorial upward circulation in association with the positive (westerly) shear, while the negative shear below the easterly maximum led to enhanced upward motion. Following the appearance of the disruption in February 2016, there were two layers of zonal wind shear in the tropics. Westerly shear in the $30-50 \mathrm{hPa}$ layer was linked to increased temperature and decreased upwelling, resulting in positive perturbations in $\mathrm{O}_{3}$ and $\mathrm{HCl}$. The easterly shear from the disruption in the 50$100 \mathrm{hPa}$ layer produced negative temperature perturbations in association with increased tropical upwelling, inducing negative perturbations in $\mathrm{O}_{3}$ and $\mathrm{HCl}$. Cold temperature anomalies extended to the tropopause level in late 2016, resulting in decreases in global stratospheric water vapor. Because the ozone number density maximum is in the $50-30 \mathrm{hPa}$ layer, the $\mathrm{QBO}$ disruption increased total $\mathrm{O}_{3}$ at the equator.

The decrease in tropical ascent during the disruption was balanced by reduced downwelling in the extratropics. This reduced extratropical downward motion decreased $\mathrm{O}_{3}$ in those regions (although the horizontal component to this circulation contributes as well). In this study we focused mostly on $\mathrm{O}_{3}$ changes; however, the response of other long-lived tracers such as $\mathrm{HCl}$ and $\mathrm{N}_{2} \mathrm{O}$ is consistent with the QBO meridional circulation induced by the disrupted QBO. While $\mathrm{HCl}$ anomalies are consistent with the $\mathrm{O}_{3}$ anomalies, the $\mathrm{N}_{2} \mathrm{O}$ anomalies have an opposite sign due to the negative vertical gradient of this tracer. The similarities in the responses of temperature and observed changes in chemical trace gases to the QBO disruption show that these composition changes are primarily dynamically driven. Trace gases show perturbed behavior compared to the past, but their response is consistent with our understanding of the QBOinduced meridional circulation.

At nearly the same time as the QBO disruption, there was one of the strongest El Niño events on record and very strong stratospheric polar vortex in early to midwinter (Cheung et al., 2016; Hu et al., 2016; Scaife et al., 2017). The interplay of these three events and their potential impact on trace gas distributions remains to be investigated. For instance, we acknowledge the possible influence of the 2015-2016 El
Niño event on tropical tropopause temperature and therefore the global redistribution of stratospheric water vapor. Furthermore, previous studies by Fioletov and Shepherd (2003, 2005) showed very strong correlations between polar and midlatitude total ozone. Ozone-depleted air inside the cold polar vortex could mix into the Northern Hemisphere midlatitudes contributing to the negative anomalies in total ozone during the 2016 boreal summer. Strahan et al. (2016) showed that the impact of Arctic ozone depletion on the midlatitudes in spring after winters with moderate depletion (such as 2016) was about $5 \mathrm{DU}$ (south of $45^{\circ} \mathrm{N}$ ). But they also found that the dynamical impact on $\mathrm{O}_{3}$ due to a strong polar vortex winter was roughly the opposite of the depletion changes, resulting in very little net impact. Furthermore, the very symmetric nature of negative anomalies around the equator during the boreal summer and fall strongly suggests a dominant role of circulation changes due to the 2015-2016 QBO disruption.

It is unclear if this QBO disruption is an event of great rarity or if similar events will reoccur. Similar disruptions with the same timing could potentially alter ozone and trace gas distributions, affecting the stratospheric climate and making it more difficult to accurately estimate climate trends. For example, a series of disruptions could drive a downward ozone trend and lead to a long-term increase in the surface UV index during the peak of northern summer.

At present, numerical models are unable to predict such events (Osprey et al., 2016), pointing to an incomplete understanding of QBO forcing mechanisms. The model failures could result from missing processes, a poor representation of necessary wave forcings, or resolution. Osprey et al. (2016) pointed out that only one event similar to that observed during 2016 was identified among the available models that produce an internally generated QBO. Our inability to simulate and/or predict a disrupted QBO will add uncertainty to future predictions of ozone and other chemical constituents from coupled chemistry climate models, as well as limit our ability to resolve statistically significant ODS-related changes in the observed $\mathrm{O}_{3}$ record. This event, whether unique or the first of many QBO disruptions, emphasizes the crucial need to continue collecting and evaluating high-quality satellite measurements to trace the impact of stratospheric dynamical changes.

Data availability. The observational data sets used in this study are publicly available. MLS data are available from the NASA Goddard Space Flight Center Earth Sciences (GES) Data and Information Services Center (DISC). SBUV total ozone data were obtained from the NASA Goddard Space Flight Center Website (https:// acd-ext.gsfc.nasa.gov/Data_services/merged/; NASA, 2017a). The MERRA-2 reanalysis fields were obtained from the NASA Earth Observing System Data and Information System (https://earthdata. nasa.gov; NASA, 2017b). Daily global radiosondes were collected at NASA/GSFC and are provided from the Global Telecommu- 
nications System (available via the NOAA/NCEP web site: ftp: //ftp.cpc.ncep.noaa.gov/wd53rl/rsonde/, NOAA Climate Prediction Center, 2017). The HALOE data set is available at http://haloe. gats-inc.com (NASA Langley Research Center, 2017), and GPS radio occultation data are obtained from the COSMIC data center at http://www.cosmic.ucar.edu/ (COSMIC Data Analysis and Archive Center, 2017).

Competing interests. The authors declare that they have no conflict of interest.

Acknowledgements. The authors acknowledge and thank Luke Oman for providing us with the vertical component of the residual circulation, $\bar{w}^{*}$, calculated from the MERRA-2 reanalysis product, and the authors also thank all those who are members of the MLS and SBUV data science and support teams. Olga Tweedy is supported by the National Science Foundation Graduate Research Fellowship Program under grant no. DGE-1232825. Support for this study was also provided under the NASA Atmospheric Composition Modeling and Analysis Program. NCAR is operated by the University Corporation for Atmospheric Research, under sponsorship of the National Science Foundation. We thank the two reviewers for their substantive comments.

Edited by: F. Khosrawi

Reviewed by: two anonymous referees

\section{References}

Andrews, D. G., Holton, J. R., and Leovy, C. B.: Middle atmosphere dynamics, 40, Academic press, 1987.

Angell, J. K. and Korshover, J.: Quasi-biennial variations in temperature, total ozone, and tropopause height, J. Atmos. Sci., 21, 479-492, 1964.

Baldwin, M., Gray, L., Dunkerton, T., Hamilton, K., Haynes, P., Randel, W., Holton, J., Alexander, M., Hirota, I., and Horinouchi, T.: The quasi-biennial oscillation, factor, 39, 179-229, 2001.

Bosilovich, M. G., Akella, S., Coy, L., Cullather, R., Draper, C., Gelaro, R., Kovach, R., Liu, Q., Molod, A., Norris, P., and Wargan, K.: MERRA-2: Initial evaluation of the climate, Series on Global Modeling and Data Assimilation, NASA/TM, 2015;104606, 2015.

Caldwell, M., Teramura, A. H., Tevini, M., Bornman, J., Björn, L. O., and Kulandaivelu, G.: Effects of increased solar ultraviolet-radiation on terrestrial plants, Ambio, 24, 166-173, 1995.

Calvo, N., Garcia, R., Randel, W., and Marsh, D.: Dynamical mechanism for the increase in tropical upwelling in the lowermost tropical stratosphere during warm ENSO events, J. Atmos. Sci., 67, 2331-2340, 2010.

Cheung, H. H., Zhou, W., Leung, M. Y., Shun, C., Lee, S., and Tong, H.: A strong phase reversal of the Arctic Oscillation in midwinter 2015/2016: Role of the stratospheric polar vortex and tropospheric blocking, J. Geophys. Res.-Atmos., 121, 13443-13457, https://doi.org/10.1002/2016JD025288, 2016.
Choi, W., Lee, H., Grant, W. B., Park, J. H., Holton, J. R., Lee, K., and Naujokat, B.: On the secondary meridional circulation associated with the quasi-biennial oscillation, Tellus B, 54, 395406, 2002.

Coy, L., Wargan, K., Molod, A. M., McCarty, W. R., and Pawson, S.: Structure and dynamics of the quasi-biennial oscillation in MERRA-2, J. Climate, 29, 5339-5354, 2016.

Coy, L., Newman, P., Pawson, S., and Lait, L. R.: Dynamics of the Disrupted 2015-16 Quasi-Biennial Oscillation, J. Climate, https://doi.org/10.1175/JCLI-D-16-0663.1, 2017.

Dunkerton, T. J.: The role of gravity waves in the quasi-biennial oscillation, J. Geophys. Res.-Atmos., 102, 26053-26076, 1997.

Frith, S. M., Kramarova, N. A., Stolarski, R. S., McPeters, R. D., Bhartia, P. K., and Labow, G. J.: Recent changes in total column ozone based on the SBUV Version 8.6 Merged Ozone Data Set, J. Geophys. Res.-Atmos., 119, 9735-9751, https://doi.org/10.1002/2014JD021889, 2014.

Funk, J. and Garnham, G.: Australian ozone observations and a suggested 24 month cycle, Tellus, 14, 378-382, 1962.

Garfinkel, C. I., Hurwitz, M. M., Oman, L. D., and Waugh, D. W.: Contrasting effects of Central Pacific and Eastern Pacific El Niño on stratospheric water vapor, Geophys. Res. Lett., 40, 41154120, 2013.

Gray, L. and Chipperfield, M.: On the interannual variability of trace gases in the middle atmosphere, Geophys. Res. Lett., 17, 933936, 1990.

Gray, L. and Pyle, J.: A two-dimensional model of the quasibiennial oscillation of ozone, J. Atmos. Sci., 46, 203-220, 1989.

Gray, L. J. and Ruth, S.: The modeled latitudinal distribution of the ozone quasi-biennial oscillation using observed equatorial winds, J. Atmos. Sci., 50, 1033-1046, 1993.

Holton, J. R. and Lindzen, R. S.: An updated theory for the quasibiennial cycle of the tropical stratosphere, J. Atmos. Sci., 29, 1076-1080, 1972.

Kinnersley, J. S. and Tung, K.-K.: Modeling the global interannual variability of ozone due to the equatorial QBO and to extratropical planetary wave variability, J. Atmos. Sci., 55, 1417-1428, 1998.

Lindzen, R. S. and Holton, J. R.: A theory of the quasi-biennial oscillation, J. Atmos. Sci., 25, 1095-1107, 1968.

Ling, X.-D. and London, J.: The quasi-biennial oscillation of ozone in the tropical middle stratosphere: A one-dimensional model, J. Atmos. Sci., 43, 3122-3137, 1986.

Livesey, N. J., Read, W. G., Wagner, P. A., Froidevaux, L., Lambert, A., Manney, G. L., Millán-Valle, L. F., Pumphrey, H. C., Santee, M. L., Schwartz, M. J., Wang, S., Fuller, R. A., Jarnot, R. F., Knosp, B. W., and Martinez, E.: Version 4.2x Level 2 data quality anddescription document, Tech. Rep. JPL D-33509 Rev. B, Jet PropulsionLaboratory, available at: http://mls.jpl.nasa.gov (last access: May 2017), 2015.

NASA: SBUV Merged Ozone Data Set (MOD), available at: https: //acd-ext.gsfc.nasa.gov/Data_services/merged/, last access: May 2017a.

NASA: NASA Earth Science Data, available at: https://acd-ext. gsfc.nasa.gov/Data_services/merged/, last access: May 2017b. NASA Langley Research Center: The Halogen Occultation Experiment (HALOE) Version 19 Data, available at: http://www. cosmic.ucar.edu, last access: May 2017. 
Newman, P., Coy, L., Pawson, S., and Lait, L.: The anomalous change in the QBO in 2015-2016, Geophys. Res. Lett., 43, 8791-8797, 2016.

Newman, P. A. and McKenzie, R.: UV impacts avoided by the Montreal Protocol, Photochem. Photobiol. Sci., 10, 1152-1160, 2011.

NOAA Climate Prediction Center: Daily global radiosonde data, available at: http://haloe.gats-inc.com, last access: May 2017.

Osprey, S. M., Butchart, N., Knight, J. R., Scaife, A. A., Hamilton, K., Anstey, J. A., Schenzinger, V., and Zhang, C.: An unexpected disruption of the atmospheric quasi-biennial oscillation, Science (New York, N.Y.), 353, 1424-1427, science.aah4156 [pii], IR: 20161006; CI: Copyright (c) 2016; JID: 0404511; ppublish, 2016.

Ramanathan, K.: Bi-annual variation of atmospheric ozone over the tropics, Q. J. Roy. Meteorol. Soc., 89, 540-542, 1963.

Randel, W. J. and Jensen, E. J.: Physical processes in the tropical tropopause layer and their roles in a changing climate, Nature Geosci., 6, 169-176, 2013.

Randel, W. J. and Wu, F.: Isolation of the ozone QBO in SAGE II data by singular-value decomposition, J. Atmos. Sci., 53, 25462559, 1996.

Randel, W. J., Garcia, R. R., Calvo, N., and Marsh, D.: ENSO influence on zonal mean temperature and ozone in the tropical lower stratosphere, Geophys. Res. Lett., 36, L15822, https://doi.org/10.1029/2009GL039343, 2009.

Scaife, A. A., Comer, R., Dunstone, N., Fereday, D., Folland, C., Good, E., Gordon, M., Hermanson, L., Ineson, S., and Karpechko, A.: Predictability of European winter 2015/2016, Atmos. Sci. Lett., 18, 38-44, 2017.
Schoeberl, M., Douglass, A., Newman, P., Lait, L., Lary, D., Waters, J., Livesey, N., Froidevaux, L., Lambert, A., and Read, W.: QBO and annual cycle variations in tropical lower stratosphere trace gases from HALOE and Aura MLS observations, J. Geophys. Res.-Atmos., 113, D05301, https://doi.org/10.1029/2007JD008678, 2008.

Stolarski, R. S., Bloomfield, P., McPeters, R. D., and Herman, J. R.: Total ozone trends deduced from Nimbus 7 TOMS data, Geophys. Res. Lett., 18, 1015-1018, 1991.

Strahan, S., Oman, L., Douglass, A., and Coy, L.: Modulation of Antarctic vortex composition by the quasi-biennial oscillation, Geophys. Res. Lett., 42, 4216-4223, 2015.

Strahan, S., Douglass, A., and Steenrod, S.: Chemical and dynamical impacts of stratospheric sudden warmings on Arctic ozone variability, J. Geophys. Res.-Atmos., 121, 11836-11851, https://doi.org/10.1002/2016JD025128, 2016.

Tevini, M.: UV-B radiation and ozone depletion: effects on humans, animals, plants, microorganisms, and materials, Lewis Publishers Boca Raton, FL, 1993.

Udelhofen, P. M., Gies, P., Roy, C., and Randel, W. J.: Surface UV radiation over Australia, 1979-1992: effects of ozone and cloud cover changes on variations of UV radiation, J. Geophys. Res.Atmos., 104, 19135-19159, 1999.

Wallace, J. M., Panetta, R. L., and Estberg, J.: Representation of the equatorial stratospheric quasi-biennial oscillation in EOF phase space, J. Atmos. Sci., 50, 1751-1762, 1993.

Zawodny, J. M. and McCormick, M. P.: Stratospheric Aerosol and Gas Experiment II measurements of the quasi-biennial oscillations in ozone and nitrogen dioxide, J. Geophys. Res.-Atmos., 96, 9371-9377, 1991. 